\title{
STRESS MAHASISWA AKIBAT PEMBELAJARAN DARING DAN \\ KOPING STRESS YANG EFEKTIF SELAMA MASA PANDEMI
}

\author{
Julita Megawati Sitohang \\ julita.sitohang027@gmail.com
}

\section{LATAR BELAKANG}

Saat ini, pandemi Covid-19 menjadi salah satu krisis kesehatan utama bagi setiap individu dari semua bangsa, benua, ras, dan kelompok sosial ekonomi. Kondisi kesehatan masyarakat terkait penularan Covid-19 dibagi menjadi enam kelompok yaitu orang sehat, orang tanpa gejala, orang dalam pemantauan, pasien dalam pengawasan, orang yang positif Covid-19 (Kemenkes RI, 2020). Infeksi virus Corona disebut COVID-19 (Corona Virus Disease 2019) dan pertama kali di China pada akhir Desember 2019. Virus ini menular dengan sangat cepat dan telah menyebar ke hampir semua negara, termasuk Indonesia, hanya dalam waktu beberapa bulan. Hal tersebut membuat beberapa negara menerapkan kebijakan untukmemberlakukan lockdown dalam rangka mencegah penyebaran virus Corona. DiIndonesia sendiri, diberlakukan kebijakan Pembatasan Sosial Berskala Besar (PSBB)untuk menekan penyebaran virus ini (WHO,2020).

Surat Edaran Mendikbud Nomor 36962/MPK.A/HK/2020 menjelaskan supaya setiap proses belajar mengajar di sekolah maupun kampus disetiap perguruan tinggi menggunakan metode daring sebagai upaya pencegahan terhadap perkembangan dan penyebaran Coronavirus disease (Covid-19). Pembelajaran secara daring diimplementasikan dengan beragam cara oleh pendidik di tengah penutupan sekolah untuk mengantisipasi virus corona. Namun implementasi tersebut dinilai tidak maksimal dan menunjukkan masih ada ketidaksiapan di kalangan pendidik untuk beradaptasi di iklim digital (Charismiadji, 2020). Banyak sekolah yang menerapkan metode pemberian tugas secara daring bagi para siswa. Penugasan itu dilakukan melalui berbagai media sosial yang tersedia, terutama whatsapp grup. Dalam kondisi darurat karena adanya virus corona seperti sekarang, bentuk penugasan yang dipandang efektif dalam pembelajaran jarak jauh.

Konsekuensinya, pengenalan konsep mengenai suatu pelajaran sebagaimana yang diterapkan dalam pembelajaran tatap muka tidak bisa berjalan dengan baik. Dalam pembelajaran tatap muka akan ada penyampaian konsep pembelajaran dan tujuannya terlebih 
dahulu. Kemudian pembelajaran berlanjut sampai pemahaman dan pengembangannya. Tahapan-tahapan tersebut dinilai tidak berjalan dengan baik dalam situasi darurat seperti sekarang (Charismiadji, 2020).

Gagapnya para pendidik, bingungnya orangtua yang mendampingi anakanaknya belajar di rumah, dan mahasiswa yang kebingungan menghadapi metodepembelajaran daring disertai dengan tumpukan tugas menyebabkan semakin meluas terjadinya kecemasan terlebih lagi dimasa pandemi Covid-19. Penelitian yang dilakukan oleh livana PH dkk (2020) menunjukkan bahwa Tugas pembelajaran merupakan faktor utama penyebab stres mahasiswa selama pandemi Covid-19. Ansietas dapat berupa perasaan khawatir, perasaan tidak enak, tidak pasti atau merasa sangat takut sebagai akibat dari suatu ancaman atau perasaan yang mengancam dimana sumber nyata dari kecemasan tersebut tidak diketahui dengan pasti (Nasir, Abdul., Abdul Muhith, 2011).

Kecemasan mempengaruhi hasil belajar mahasiswa, karena kecemasan cenderung menghasilkan kebingungan dan distorsi persepsi. Distorsi tersebut dapat mengganggu belajar dengan menurunkan kemampuan memusatkan perhatian, menurunkan daya ingat, mengganggu kemampuan menghubungkan satu hal dengan yang lain (Kaplan dan Saddock, 2005). Sebagaimana penjelasan diatas, maka artikel ini akan membahas Tingkat Stres Pada Mahasiswa yang Melakukan Pembelajaran Daring Pada Masa Covid-19 serta koping stress yang efektif selama masa pandemi covid 19.

\section{METODE}

Metode yang akan digunakan dalam pembuatan karya ilmiah ini adalah dengan menggunakan metode Literature Review. Penelitian kepustakaan atau kajian literatur (literature review atau literature research) merupakan penelitian yang mengkaji atau meninjau secara kritis pengetahuan, gagasan, atau temuan yang terdapat di dalam tubuh literature berorientasi akademik (academic-oriented literature), serta merumuskan kontribusi teoritis dan metodologisnya untuk topic tertentu,Cooper dan Taylor (Farisi, 2010). Fokus penelitian kepustakaan adalah menemukan berbagai teori, hukum, dalil, prinsip, atau gagasan yang digunakan untuk menganalisis dan memecahkan masalah terkait stress mahasiswa selama pembelajaran daring di masa pandemi. Setelah melakukan kajian kepustakaan, diharapkan mendapat pengetahuan yang baru oleh pembaca.

\section{HASIL}


Stress berasal dari bahasa latin yang artinya tegang atau genting, secara harfiah stress dapat didefiniskan stimulus atau situasi yang memicu emosi negatif yang menciptakan tuntutan fisik dan psikis pada individu dalam menghadapi ancaman (Khayat, 2007). Awal mula teori stress berasal penelitian Canon pada tahun 1929 kemudian diadopsi oleh Mayer pada tahun 1951 yang melatih para dokter untuk menggunakan riwayat hidup pasien sebagai sarana diagnostik karena banyak dijumpai kejadian traumatik pada pasien yang menyebabkan penyakit (Khayat, 2007).

Walaupun teori stres terus berkembang dari masa ke masa, tetapi secara fundamental teori stres hanya digolongkan atas tiga pendekatan. Tiga pendekatan terhadap teori stres tersebut adalah: (1) stres model stimulus (rangsangan), (2) stres model response (respons), dan (3) stres model transactional (transaksional) (Lyon, 2012). Stres Sebagai Stimulus Menurut konsepsi ini stres merupakan stimulus yang ada dalam lingkungan (environment). Individu mengalami stres bila dirinya menjadi bagian dari lingkungan tersebut. Dalam konsep ini stres merupakan variable bebas sedangkan individu merupakan variabel terikat.

- $\quad$ Stres Sebagai Respon Konsepsi kedua mengenai stres menyatakan bahwa stress merupakan respon atau reaksi individu terhadap stressor. Dalam konteks ini stress merupakan variable tergantung (dependen variable) sedangkan stressor merupakan variable bebas atau independent variable.

- Stres Sebagai Interaksi antara Individu dengan Lingkungan Menurut pandangan ketiga, stress sebagai suatu proses yang meliputi stressor dan strain dengan menambahkan dimensi hubungan antara individu dengan lingkungan. Interaksi antara manusia dan lingkungan yang saling mempengaruhi disebut sebagai hubungan transaksional. Dalam konteks stres sebagai interaksi antara individu dengan lingkungan, stres tidak dipandang sebagai stimulus maupun sebagai respon saja, tetapi juga suatu proses di mana individu juga merupakan pengantara (agent) yang aktif, yang dapat mempengaruhi stressor melalui strategi perilaku kognitif dan emosional.

- Stres Sebagai Hubungan antara Individu dengan Stressor Stres bukan hanya dapat terjadi karena faktor-faktor yang ada di lingkungan. Bahwa stressor juga bisa berupa faktor-faktor yang ada dalam diri individu, misalnya penyakit jasmani yang dideritanya, konflik internal, dst. Oleh sebab itu lebih tepat bila stres dipandang sebagai hubungan antara individu dengan stressor, baik stressor internal maupun eksternal. 
Dari paparan di atas dapat dipahami bahwa Stress adalah respons organisme untuk menyesuaikan diri dengan tuntutan-tuntutan yang berlangsung. Tuntutan tersebut dapat berupa hal-hal yang faktual terjadi, atau hal-hal baru yang mungkin akan terjadi, tetapi dipersepsi secara aktual. Apabila kondisi tersebut tidak teratasi dengan baik maka terjadilah gangguan pada satu atau lebih organ tubuh yang mengakibatkan yang bersangkutan tidak dapat menjalankan fungsi pekerjaannya dengan baik. Dengan redaksi yang lebih sederhana, stress adalah suatu keadaan tidak mengenakkan atau tidak nyaman yang dialami oleh individu dan keadaan tersebut mengganggu pikiran, emosional, tindakan atau perilaku dalam kehidupan sehari-hari. Kondisi tersebut bersifat individual dan subjektif. Artinya kondisi stress yang dialami oleh setiap orang tidak sama dan cara penanggulangannya pun tidak sama karena sifatnya subyektif dan pribadi.

\section{PEMBAHASAN}

Pada akhir tahun 2019 dunia diguncangkan oleh munculnya sebuah virus misterius yang dikenal dengan COVID-19 (Corona Virus Disease 2019). Virus ini pertama kali muncul di Wuhan China yang menular dengan sangat cepat dan telah menyebar hampir ke semua negara, termasuk negara Indonesia hanya dalam waktu beberapa bulan. Mengatasi penularan Virus tersebut pemerintah telah mengeluarkan berbagai kebijakan, seperti isolasi, social and physical distancing hingga Pembatasan Sosial Berskala Besar (PSBB). Kondisi ini mengharuskan warga untuk tetap di rumah saja, bekerja, beribadah dan belajar di rumah. Kebijakan ini membawa dampak yang sangat besar terhadap lembaga pendidikan, sehingga kementrian diberbagai negara telah mengambil langkah di setiap Sekolah dan Universitas untuk melakukan pembelajaran secara online atau daring (dalam jaringan).

Kemendikbud mengeluarkan surat edaran instruksi kepada seluruh universitas yang ada di Indonesia untuk melakukan perkuliahan jarak jauh (daring) secara online. Kuliah daring atau yang biasa disebut dengan sebutan kuliah online adalah proses belajar mengajar berbasis internet yang dilakukan oleh mahasiswa, maupun dosen, dimana peserta dapat mengakses materi, saling berinteraksi,mendiskusikan materi, dan mengembangkan diri lewat pengalaman belajar berbasis online (Universitas Indonesia,2020). Tujuan Program Kuliah Daring Indonesia Terbuka dan Terpadu menurut Kemendikbud (2014), yaitu : (1) Meningkatkan kualitas dan relevansi layanan pendidikan, (2) Meningkatkan kepastian mendapat layanan pendidikan yang baik, (3) Meningkatkan keterjangkauan layanan pendidikan, (4) Meningkatkan ketersediaan layanan pendidikan, (5) Meningkatkan kesamaan dalam mendapatkan layanan pendidikan yang baik. 
Dalam proses pelaksanaannya, perkuliahan daring menimbulkan beberapa masalah. Banyak mahasiswa yang mengeluh karena kuliah berbasis online membuat mereka kurang paham akan materi-materi perkuliahan yang disampaikan, dan pemberian tugas yang jumlahnya lebih banyak dibandingkan kuliah seperti biasa. Oleh karena itu, tidak sedikit mahasiwa mengalami stres dikarenakan sistem perkuliahan daring ini.

Pembelajaran daring ini bertujuan untuk meningkatkan kewaspadaan dan proses menghentikan penyebaran Virus melalui interaksi langsung di antara orang banyak. Pembelajaran daring yang telah disepakati sebagai solusi terhadap kegiatan belajar mengajar ditengah pandemi Covid-19 ini, ternyata tidak lepas dari permasalahan yang menjadi hambatan dalam pelaksanaannya. Banyak mahasiswa yang mengeluh kesusahan dengan dilaksanakannya pembelajaran daring tersebut, mahasiswa kurang menerima diadakannya pembelajaran daring tersebut namun dengan terpaksa harus mengikuti sesuai dengan anjuran pemerintah demi membantu untuk mengurangi penularan virus Covid-19. Kegiatan pembelajaran perlu dipertimbangkan efektivitas artinya sejauh mana tujuan yang telah ditetapkan dapat dicapai. Keefektifan pembelajaran tidak hanya ditinjau dari segi tingkat prestasi belajar saja, melainkan harus pula ditinjau dari segi proses dan sarana penunjang. Keefektifan dapat diukur dengan melihat minat mahasiswa terhadap kegiatan pembelajaran.

Mahasiswa sebagai individu yang menuntut ilmu di perguruan tinggi dalam kegiatannya tidak terlepas dari stres. Menurut Kumar (2011) stres merupakan bagian dari faktor yang mempengaruhi proses dalam pendidikan dan kesejahteraan mahasiswa. Waghachavare et al (2013) menyampaikan berdasarkan hasil penelitiannya bahwa stres akademik merupakan salah satu hal penting yang menjadi salah satu penyebab stres. Stres akademik adalah stres yang berhubungan dengan proses menjalani kegiatan pendidikan yang terjadi dalam masa pendidikan yang disebabkan karena tuntutan yang timbul selama seseorang dalam masa pendidikan dan terjadi bila mengalami ketegangan emosi ketika terjadi kegagalan dalam memenuhi tuntutan tersebut (Thawabieh and Naour, 2012). Menurut Kumar (2011) bahwa mahasiswa yang mengalami stres dapat menjadi mudah marah, menunjukkan kurangnya konsentrasi, penurunan prestasi akademik, hubungan interpersonal yang buruk, insomnia dan sering absen dalam proses pendidikan.

Schneiders (dalam Hartinah 2008: 186) mengungkapkan bahwa kegagalan dalam melakukan penyesuaian diri secara positif dapat mengakibatkan individu bertingkah laku serba salah, tidak tararah, emosional, sikap yang tidak realistic dan agresif. Hal ini tentunya tidak lepas dari faktor-faktor yang mempengaruhi penyesuaian diri seseorang yaitu kondisi fisik, (hereditas, system utama tubuh dan kesehatan fisik), kepribadian (kemauan dan 
kemampuan untuk berubah, pengaturan diri, realisasi diri dan intelegensi), proses belajar (bejaran, pengalaman, latihan, determinasi diri), lingkungan (lingkungan keluarga, sekolah, masyarakat) dan agama serta budaya.

Respon stres dari setiap mahasiswa berbeda, tergantung pada kondisi kesehatan, kepribadian, pengalaman sebelumnya terhadap stres, mekanisme koping, jenis kelamin, dan usia, besarnya stressor, dan kemampuan pengelolaan emosi dari masingmasing individu (Potter \& Perry, 2012). Menurut Alazayyat dan Algamal (2014) bahwa stres dapat memicu seseorang untuk berperilaku negatif dan berperilaku positif. Dalam hal ini penilaian seseorang terhadap stressor akan menentukan upaya dalam menghadapi stressor. Menurut Stuart dan Sundeen (2016), bahwa semua upaya yang diarahkan untuk mengelola stres baik itu yang konstruktif maupun yang destruktif disebut dengan koping.

Sebelum mengelola stress perlu diketahui terlebih dahulu gejala-gejala Stress pada masa Pandemi Covid-19. Di antara tanda-tandanya antara lain:

1. memiliki rasa khawatir atau takut yang berlebihan sehingga berpikir yang tidak rasional 2. memiliki pikiran negatif terhadap orang yang memiliki tanda-tanda penderita 3. mencari berita mengenai Covid-19 yang berlebihan sehingga tidak dapat memilah berita yang akurat dan dapat memunculkan kecemasan yang membuat seseorang mengalami sulit tidur

4. sakit kepala, serta sakit fisik lainnya.

Stress dapat mempengaruhi kondisi fisik, mental dan emosi seseorang. Maka dari itu penting bagi setiap orang untuk memiliki pengetahuan dan kemampuan dalam mengatasi stress. Dengan memahami teori dan konsep stress, seseorang dapat memiliki kuasa penuh dalam mengontrol diri dan emosinya sehingga ia dapat mengoptimalkan kemampuan dan kekuatan yang dimilikinya. (In The Know:2014) Yang perlu ditekankan juga dalam mengatasi stress ialah bahwa kita tidak memiliki kendali terkait penyebab stress, tetapi kita mampu mengontrol bagaimana kita bereaksi terhadap stress tersebut. (U.S. Department of Veterant Affairs,: 2014)

Menurut Lazzarus dan Folkman, coping stress merupakan suatu proses di mana individu mencoba untuk mengelola jarak yang ada antara tuntutan-tuntutan (baik itu tuntutan yang berasal dari individu maupun tuntutan yang berasal dari lingkungan) dengan sumber-sumber daya yang mereka gunakan dalam menghadapi situasi penuh tekanan. Secara umum, stress dapat diatasi dengan melakukan transaksi dengan lingkungan di mana hubungan transaksi ini 
merupakan suatu proses yang dinamis. (Lazarus \& Folkman:1984)., Terdapat dua macam fungsi, coping stress, yaitu:

\section{- Emotion-focused coping}

Digunakan untuk mengatur respons emosional terhadap stress. Pengaturan ini melalui perilaku individu, seperti penggunaan obat penenang, bagaimana meniadakan faktafakta yang tidak menyenangkan, melalui strategi kognitif. Bila individu tidak mampu mengubah kondisi yang stressful, individu akan cenderung untuk mengatur emosinya.

\section{- Problem-focused coping}

Untuk mengurangi stressor, individu akan mengatasi dengan mempelajari cara-cara atau keterampilan-keterampilan yang baru. Individu akan cenderung menggunakan strategi ini bila dirinya yakin akan dapat mengubah situasi. Metode atau fungsi masalah ini lebih sering digunakan oleh orang dewasa.

Ada delapan strategi coping yang berbeda yang secara umum dikenal dalam psikologi, yaitu:

1. konfrontasi,

2. mencari dukungan sosial,

3. merencanakan pemecahan masalah dikaitkan dengan problem-focused coping,

4. kontrol diri,

5. membuat jarak,

6. penilaian kembali secara positif,

7. menerima tanggung jawab,

8. lari atau penghindaran.

Tidak ada satu metode pun yang dapat digunakan untuk semua situasi stress. Tidak ada strategi coping yang paling berhasil. Strategi coping yang paling efektif adalah strategi yang sesuai dengan jenis stress dan situasi. Keberhasilan coping lebih tergantung pada penggabungan strategi coping yang sesuai dengan ciri masing-masing kejadian yang penuh stress, daripada mencoba menemukan satu strategi coping yang paling berhasil.

Penyesuaian yang sifatnya problem solving terhadap stress, merupakan jenis penyesuaian terhadap stress yang bersifat disadari, berupaya menghilangkan sumber stres, tidak tergesa-gesa atau lebih terarah, ada strategi tertentu, dan lebih efektif. Ini dapat dilakukan dengan memodifikasi diri agar lebih toleran terhadap stress atau memodifikasi situasi yang menimbulkan stress.

PMI menyebutkan 5 teknik manajemen stress dalam buku Panduan Manajemen Stres. 


\section{Mengenal diri sendiri.}

Mengetahui kekuatan, kelemahan, hal-hal yang disukai dan yang tidak disukai dapat membantu kita memetakan ke arah mana kehidupan akan kita bawa. Dengan mengenal diri sendiri, akan lebih mudah untuk menentukan cara dan strategi apa yang tepat untuk meringankan stress.

\section{Peduli diri sendiri.}

Setelah mengetahui diri secara mendalam, maka kebutuhan-kebutuhan dan kewajiban juga akan tampak. Memenuhi kebutuhan diri sendiri merupakan salah satu cara untuk mengatur stres yang dihadapi. Peduli akan diri sendiri dapat dimulai dengan mencoba pola hidup sehat, bersosialisasi dengan teman dan sanak saudara, merencanakan kegiatan yang realistis dan menjalani hobi.

\section{Perhatikan keseimbangan.}

Sebagaimana manusia yang dianugerahi beberapa aspek dalam dirinya, maka kelima aspek ini harus dipelihara dan dipenuhi secara seimbang. Lima aspek pemeliharaan diri ini adalah: Aspek Mental Emosional, Aspek Intelektual, Aspek Fisik, Aspek Spiritual dan Aspek Rekreasional

4. Bersikap proaktif dalam mencegah gangguan stres dengan merawat kelima aspek di atas dengan baik dan rutin agar menjadi sosok yang resilien dan memiliki kemampuan dan kekuatan lebih dalam menghadapi stres.

\section{Sinergi}

Langkah-langkah sebelumnya ialah satuan proses yang perlu dilakukan secara berurutan dan terpadu dengan kehendak dan kesadaran penuh untuk bangkit dari keterpurukan dan stres. (Palang Merah Indonesia: 2015)

WHO merumuskan strategi untuk menghadapi stress selama pandemi Covid-19: a. Merasa sedih, tertekan, bingung, takut dan marah adalah hal yang lumrah selama krisis terjadi. Berbincang dan berbagi cerita dengan orang-orang yang dapat dipercayai bisa membantu mengurangi rasa tertekan yang dialami.

b. Selama pandemi ini, berdiam di rumah lebih dianjurkan untuk meminimalisir penyebaran virus dan kontak fisik dengan orang banyak. Menjaga gaya hidup sehat dengan asupan gizi yang cukup, pola tidur yang baik, olahraga dan berinteraksi dengan orang-orang yang disayang bisa dilakukan selama berdiam di rumah.

c. Menghindari rokok, alkohol dan narkotika untuk menyelesaikan masalah emosi. d. Mencari fakta-fakta dan info terbaru yang dapat membantu dalam menentukan tahap pencegahan yang tepat dan menghindari berita-berita yang tidak valid dan kredibel. 
e. Mengurangi kecemasan dengan membatasi media yang menyebarkan informasi yang membuat semakin cemas dan takut.

f. Mengoptimalkan kemampuan yang dimiliki untuk mengatur emosi selama masa pandemi ini.

Setiap orang memiliki cara mengatasi stres yang berbeda-beda, cara ini perlahan berubah menjadi kebiasaan jika dilakukan terus menerus. Ada yang menghadapi stress dengan cara yang sehat, atau justru memperburuk keadaan dengan melakukan hal-hal di luar batas. Diana Ballesteros dan Janis Whitlock mengemukakan dua jenis cara mengatasi stress, yakni:

a. Strategi yang baik dalam menghadapi stres: berolahraga secara rutin, memiliki alokasi waktu untuk beristirahat dan perawatan diri, menyeimbangi antara bekerja dan bermain, membuat manajemen waktu dan meditasi.

b. Strategi yang tidak baik dalam menghadapi stress: Mengonsumsi alkohol dan narkotika, melakukan kejahatan dan kriminal, menunda-nunda pekerjaan, menyakiti diri sendiri dan makan/minum berlebihan. (Ballesteros \& Whitlock 4:2009)

Masyarakat Indonesia yang religius memandang Covid-19 sebagai ujian yang harus dilalui. Berpikir positif dengan selalu menjaga imunitas tubuh dan spiritualitas menjadi salah satu cara agar terhindar dari stress. Memanfaatkan waktu yang sebaik-baiknya untuk beraktivitas secara positif dengan tetap memperhatikan protokol kesehatan menjadi solusi dalam menghadapi stress di masa pandemi Covid-19.

\section{PENUTUP}

Stress adalah respons organisme untuk menyesuaikan diri dengan tuntutan-tuntutan yang berlangsung. Tuntutan tersebut dapat berupa hal-hal yang faktual terjadi, atau hal-hal baru yang mungkin akan terjadi, tetapi dipersepsi secara aktual. Apabila kondisi tersebut tidak teratasi dengan baik maka terjadilah gangguan pada satu atau lebih organ tubuh yang mengakibatkan yang bersangkutan tidak dapat menjalankan fungsi pekerjaannya dengan baik. Dengan redaksi yang lebih sederhana, stress adalah suatu keadaan tidak mengenakkan atau tidak nyaman yang dialami oleh individu dan keadaan tersebut mengganggu pikiran, emosional, tindakan atau perilaku dalam kehidupan sehari-hari. Kondisi tersebut bersifat individual dan subjektif. Artinya kondisi stress yang dialami oleh setiap orang tidak sama dan cara penanggulangannya pun tidak sama karena sifatnya subyektif dan pribadi. Stress dapat mempengaruhi kondisi fisik, mental dan emosi seseorang. Maka dari itu penting bagi setiap orang untuk memiliki pengetahuan dan kemampuan dalam mengatasi stress. Dengan 
memahami teori dan konsep stress, seseorang dapat memiliki kuasa penuh dalam mengontrol diri dan emosinya sehingga ia dapat mengoptimalkan kemampuan dan kekuatan yang dimilikinya Memanfaatkan waktu yang sebaik-baiknya untuk beraktivitas secara positif dengan tetap memperhatikan protokol kesehatan menjadi solusi dalam menghadapi stress di masa pandemi Covid-19.

\section{DAFTAR PUSTAKA}

Agustiningsih, N. (2019). Gambaran stress akademik dan strategi koping pada mahasiswa keperawatan. Jurnal Ners dan Kebidanan. 6(2), 241-250.

Fanani, Q., Jainurakhma, J. (2020). Kemampuan penyesuaian diri mahasiswa terhadap pembelajaran daring ditengah pandemi covid-19. Jurnal Komtekinfo. 7(4), 285-292.

Hanifah, N.,dkk. (2020). Strategi coping stess saat kuliah daring pada ahasiswa psikologi angkatan 2019 universitas andalas. Jurnal Psikologi Tabularasa. 15(1), 29-43.

Harahap, A.C.P., Dinda, P.H., Samsul, R.H. (2020). Analisis tingkat stress akademik pada mahasiswa selama pembelajaran jarak jauh dimasa covid-19. Jurnal Kajian Konseling dan Pendidikan. 3(1), 10-14.

Jannah, R. (2021). Tingkat stress mahasiswa mengikuti pembelajaran daring pada masa pandemi covid-19. Jurnal Riset dan Pengabdian Masyarakat. 1(1), 130-146.

Kusnayati, A. Dkk. (2020). Pengaruh teknologi pembelajaran kuliah online di era covid-19 dan dampaknya terhadap mental mahasiswa. Jurnal Edukasi dan Teknologi Pembelajaran. 1(2), 153-165.

Lubis, H., Ayunda, R., Miranti, R. (2021). Stress akademik mahasiswa dalam melaksanakan kuliah daring selama masa pandemi covid-19. Jurnal Psikologi. 10(1), 31-39.

Muslim, M. (2020). Manajemen stress pada mahasiswa pada masa pandemi covid-19. Jurnal Manajemen Bisnis. 23(2), 191-201.

Simamora, N., Lubis, I.S., Situmorang, D. (2021). Efektivitas pembelajaran daring terhadap mahasiswa pada masa pandemi covid-19. Jurnal Basasasindo. 1(1), 1-9.

Sinuraya, B., dkk. (2020). Mengelola emosi mahasiswa dalam pembelajaran daring melalui sumber data digital masa pandemi covid-19. Alfuad Journal. 4(2), 88-100. 